\title{
PSYCHOLOGICAL FEATURES OF INTERPERSONAL COMMUNICATION OF SENIOR PRESCHOOLERS IN THE TRANSITION TO SCHOOL EDUCATION
}

\author{
Anastasia Klimenko \\ Department of Applied Psychology \\ Institute of Human Sciences \\ Borys Grinchenko Kyiv University \\ 18/2 Bulvarno-Kudriavska str., Kyiv, Ukraine, 04053 \\ mirt9307@gmail.com
}

\begin{abstract}
The article provides an in-depth scientific understanding of the interpersonal communication of senior preschoolers as a basic factor in their social readiness for school. A new approach to the development of interpersonal communication of children of senior preschool age in the process of interactive learning and gaming activities is developed and substantiated. Psychological features and socio-psychological content of interpersonal communication of senior preschoolers in the transition to schooling are determined.

The features of relationships between children and adults and peers at the stage of transition from senior preschool age to school are revealed, the specifics of relationships during the educational process due to its fundamental changes are revealed, the socio-psychological and psychological conditions affecting the process of formation of these relations at the transition stage from senior preschool to schooling are revealed. The main causes of the socio-psychological need for early learning and its possible negative consequences are highlighted. The most important changes in the public consciousness and in the consciousness of the pedagogical and educational community are determined by the essence of the phenomenon of early learning, as well as the factors and conditions of its effectiveness. The intrinsic value of each child's period is emphasized. It justifies the importance of enhancing the professional readiness of psychologists and educators of preschool educational institutions to implement a psychologically justified strategy of advanced training for senior preschoolers using a special program of psychological support for the personal development of children in conditions of organized didactic interventions aimed at accelerating their mental development. The results of studies of modern psychologists regarding the effects of early learning are summarized.
\end{abstract}

Keywords: individuality, social development, zone of proximal development, early learning, psychological intervention.

\section{Introduction}

At the beginning of the XXI century, the problem of preparing and transferring children of senior preschool children to schooling has long been known in child psychology for a relatively new meaning and content. This led to a number of sociocultural, informational, political, psychological and other challenges facing the Ukrainian society and the national education system at the new - "informational", "networked" stage [1]. The intentions to be "better", "appropriate", "competitive", etc., which significantly increased in the context of Ukraine's integration into the European Union, activated the ideas of reforming and innovating the national education system in order to harmonize it with European models and exacerbated many methodological and methodological discussions of scientists and educators, including that the teaching and socialization of children "according to new, European standards" should start at an earlier age than it was before, and therefore, is called "advance" mode. Under these conditions, the majority of children of preschool age received the status of junior schoolchildren, when the leading activity in the life of a child is a role-playing game. With its help, the basic skills of interpersonal and social communication are formed. Preschoolers were immersed in a social situation of development that was not too natural for them. School life, where the leading is an organized and quite strictly settled learning activities. Consequently, there is reason to assume that the transformation of the social situation of the development of children 5-6 years of age due to their reorientation from play (role-playing) activity to educational, intellectual, will indeed lead to their advanced mental development. However, this will occur due to the restriction of their social and socio-psychological development, for which 5-6 years is a very important, optimal, "sensitive" period of life [2]. 


\section{The aim of the article}

Theoretically substantiate the phenomenon of interpersonal communication of senior preschoolers as a factor in their successful transition to schooling.

\section{Socio-psychological characteristics of interpersonal communication of senior preschoolers in the transition to school}

The analysis of approaches to the study of the phenomenon of interpersonal communication of senior preschoolers in the transition to school communication raises many questions. They are connected with the abilities and abilities of children for relatively early, advanced intellectual development and organized learning. These questions are in principle not new and are widely represented in the pedagogical and psychological literature. In particular, many well-known researchers of the Soviet time $[2,3]$ suggested the expediency of accelerated, that is, such that it is ahead of the actual age-related possibilities and needs of children, development in order to improve and expand the boundaries of their knowledge and maximize their capabilities, for the expansion of suitable and appropriate for this psychological means [2].

However, on the other hand, they noted the unique uniqueness, the natural "age appropriated" and intrinsic value of each period of childhood. The concept of "sensitive periods of development" of the child is formulated, which provides that the re-emphasis of a preschooler on an activity unnatural for it can be considered as an intervention during natural development. Such an intervention can have only positive, but also negative consequences. Therefore, it is unreasonable to ignore the sensitive possibilities of this unique age period of children's life. The resulting loss is difficult to recover.

Consequently, there is reason to assume that the transformation of the social situation of the development of children 5-6 years of age due to their reorientation from play (role-playing) activity to educational, intellectual, will indeed lead to their advanced mental development. However, this will occur due to the restriction of their social and socio-psychological development, for which 5-6 years is a very important, optimal, "sensitive" period of life. [2] In this context, it should be noted that many well-known Ukrainian and foreign scientists and practitioners emphasize extremely high plasticity and adaptability of the child's psyche, thanks to which children are, indeed, extremely sensitive to various methods of the so-called "early learning" (reading, bills, playing musical instruments, learning knowledge encyclopedias, foreign languages, etc. $[4,5]$

However, at the same time, the question that the high adaptive abilities of the child's psyche have a reverse side also eludes time. The active adaptation of the child to something one can inhibit its adaptive capacity relative to something else, no less important. For example, accelerated cognitive-mental development initiated by an adult environment can inhibit the development of social emotions and the communicative sphere. In particular, the acquisition of the necessary social skills and interpersonal communication skills, which the child is able to acquire only in the process of high-quality and "age appropriated" game activity. Preschool childhood is not a preparatory stage for a child to further school and adulthood. This is a special, unique and self-sufficient period of human life. During which laid the foundations of human nature and functioning. Universal human qualities: sociability, focus on the position of another, the ability to act together and master their behavior, "social" emotions, etc. [3].

And now in the world professional literature there is a lot of evidence that the development of these social qualities (the peak of which falls on 5-6 years) successfully occurs specifically "preschool" activities - games, active perception of fairy tales, artistic creativity, design, etc.

According to the psychologist L. Vygotsky, the formation and development of all mental functions of a person in the preschool period of life occurs "around perception, through perception and with the help of perception". And this happens in the process of realization of the most natural for this age activities - subject-game and game. [2] It is these activities that have the greatest developmental potential for the full development of the child. As for organized educational activities, it is not natural for this age, and therefore its implementation requires: 
1) additional efforts from its initiators;

2) additional and not always justified efforts on the part of the child, to whom this initiative (actually, intervention, because this initiative is taking place, and despite the natural age possibilities of the child) is directed.

Ignoring this exposes a child's development to multiple risks. As the daily pedagogical and educational practice shows, recently not only the number of evidence of "school maladjustment" has increased, but also more diverse than its manifestation, incl. and those that attest to the discrepancy between the mental and social development of children, and many school psychologists and practicing educators associate this with the transition of 5-6 years old children to school, which places high demands on their socio-psychological competence, i. h in interpersonal communication, however, this competence was not properly formed at the time of the transition to schooling.

When raising a child, parents naturally take care of their health, nutrition, physical dexterity and intellectual development. For these concerns, few people think about what kind of personality a child grows and how parents can influence its formation.

The result of the full-fledged development of the personality should be life competence - the ability to act boldly, inventively, rationally, rely on your own strength, not get lost in an unfamiliar situation, make the right decisions, determine your place in the peer group.

During the preschool childhood, in order to successfully adapt to the conditions of the school learning environment, the following basic personality qualities should be formed: independence, diligence, humanity, self-love, responsibility, prudence, justice, self-control, creativity.

Often parents complain that it is difficult for preschoolers to communicate. All children are different, and each child has different problems.

For example, it is very difficult for shy children to make first contact. They are afraid of ridicule, refusal, evaluation by peers [6].

In other children who seem and communicate quite easily and naturally, but communication does not bring the desired satisfaction.

This happens because at preschool age, children are just beginning to master the subtleties of communication. They still do not know how to be flexible, to predict the behavior of others, to refrain from provocations. In addition, childish impulsiveness, the inability to control oneself, makes itself felt [6].

The older a child becomes, the more complex and multifaceted relationships she can build with others. But if read, write, count it will be taught necessarily, then they do not learn to communicate almost anywhere. Special difficulties are experienced by children, who for various reasons have a limited circle of friends. Because it is important not only the ability to meet, but also the ability of the child to maintain relationships, calmly respond to quarrels and be able to lead them correctly [6].

It should be noted that children's conflicts are necessary for the relationship to develop, so that children can train their communication skills. However, everything should be respected. If a child often quarrels with other children and with adults, then there is nothing good about this. Gradually, the child develops a negative image, and others begin to avoid it. In order for a child to be a self-confident person, one must teach to avoid sharp corners in communication and to resolve any conflicts [6].

The older a child becomes, the more impressions he gets. A child may receive completely different information. At the same time, consciousness is not yet ready for everything that happens in adult life [6].

For example, it is very difficult for a child to perceive the theme of death and everything connected with it. It is frightened by the unknown, as well as by phenomena that are not yet subject to children's understanding. We, adults, know for sure that the animated hero is painted by artists and can never get into real life from its screen world. But the child very often carries fairy-tale characters in real life, and they constantly visit it as very real fears. That is, growing up a child is not always accompanied by a decrease in anxiety and a decrease in the number of fears. In vulnerable and well-developed children, everything happens the other way around.

Five-, six-year-old children are very afraid of getting lost, going into the dark, afraid of dogs and harsh, loud sounds. Some babies still have fear of strangers. Unlike younger children, senior preschoolers have a well-developed imagination, which makes their fears very bright and strong. 
Computer games also increase the amount of fear. After all, monsters like jumping out of a computer screen [6].

Some children are practically afraid of nothing, while others are the opposite, because each person has its own type of nervous system. Excitable, impressionable children are in a state of constant anxiety and are afraid of everything. If we compare the list of fears of such a child and a child with a balanced nervous system, then in the first one there will be much more fears. Children also suffer from fears, in whose families conflicts often arise between adults, and even children are very sensitive to very demanding and strict parents [6].

What is important for teaching and communicating a child is imagination - the unique ability of the human brain. It allows to imagine what is not yet in the world, in our thoughts to do what is beyond our power to do in reality. For some reason, many believe that it is not worthwhile to purposely develop the imagination of a child that all children easily fantasize. But it is not. Most children find it difficult to complete tasks in which something needs to be presented, redone [6].

Modern toys almost do not provide for creativity, cartoons are very specific and almost do not allow the child to come up with something and think out. Computer games generally force a kid to move all the time using a simple algorithm [6].

Creativity can play an important role in the life of the child, as well as helping it in adult life. Imagination gives a person the opportunity to reproduce complex images in mind; it is closely connected with such important cognitive processes as memory and thinking. So, the richer the child's imagination is, the easier it will be for it to learn. Children with well-developed imagination never get bored, and they are also popular in the children's team. Since they are very interesting companions, they easily come up with games with new stories [6].

Five to six years of age is very important for the formation of self-esteem. Everyone knows how you treat yourself, so others will treat you. If a person allows itself to criticize its actions, speak badly about itself, then the attitude of the environment will not be the best, and perhaps even worse. It is necessary to bring up the child so that it was interesting for it to live, so that unnecessary fears would not interfere, to communicate was easy, so that the child would not be afraid to express its thoughts and ideas [6].

Children of senior preschool age should be able to independently invent fairy tales, stories, use various means of expression, take an interest in other people's arguments and evidence, and use them themselves. Senior preschoolers should be proactive in communicating: sharing impressions with peers, asking questions, engaging peers and elders in communication. Children 6-7 years of age notice peer speech errors, correct them, use simple concepts, their own broadcasting acquires purity, becomes grammatically correct, expressive [7].

Children of primary school age master the following communicative language skills: the ability to ask questions, expressing surprise, doubt, clarification, guess, prediction; the ability to state, expressing agreement, confirmation, judgment, effect, reference, promise; the ability to deny, expressing refusal, denial, disagreement; the ability to inspire action, expressing a request, invitation, order, proposal, wish [7].

The most favorable situation for the development of communicability is the situation in which the game partner or the adult should explain something and convince. Activity and independence in activities makes it easier for children to master the speech: communication with adults and peers, the ability to clearly express their own judgment, to accompany their actions with speech. Due to this, in the preschool age, the child is characterized by high speech activity [7].

For the organization of learning to communicate, so that it contributes to the development of communication skills, it is necessary to take into account the potential capabilities of the child. So in the first place in the education system should be the content of the needs of children of a certain age in certain social and ethical conditions. The needs of the child should be content and be embedded in the content of education.

Children have an increased need for motor activity, has its own patterns of development at each age. The development of motor activity creates a desire to speak and communicate with others. When a child sits motionless for a long time, fatigue increases. As a result, the desire to speak and take part in communication decreases or completely disappears. The development of the child's 
motor activity enhances its attention, contributes to the development of perseverance, endurance, and self-confidence [7].

The ability to perceive oneself adequately by the feelings of others is the basis of communication skills, which are further improved in elementary school.

\section{Research results}

In the conditions of transition of a child of 5-6 years to school, its natural resources are mainly spent on educational activities, and this is due to the development of other functions and skills that she needs, including skills of self-service (often necessary household and social skills are not properly formed in them: tying shoelaces, buttoning buttons, cutting bread, etc.) and interpersonal communication. The result is disharmonious communication with the subjects of the future school life, which ultimately leads to emotional and neurotic disorders, loss of academic motivation, the emergence of so-called school phobias, other signs of school maladjustment and even serious mental developmental disabilities. This is especially true of boys, in which the natural rate of maturation of the central nervous system, and especially the frontal areas of the brain, and - as a result - their assimilation of the norms and rules of social interaction is slower than in girls [8-10]

American studies confirm the positive impact of high-quality preschool education on the intellectual and social development of children of senior preschool age. Studies have shown that preschool institutions can play an important role in combating social exclusion and help facilitate the adaptation process (in particular, children from low-income families). At the same time, the positive impact on the child's development of preschool education institutions is closely connected with the peculiarities of the family structure. The experience of American scientists points to the relationship between the time a child spent in preschool and the effectiveness of the adaptation process in primary school [11].

That is, taking into account the findings of American scientists, such aspects as the quality and quantity of hours spent by a child in a preschool institution can be considered as more favorable factors for the social and intellectual development of a child, especially from families in difficult social situations. Thus, the negative impact of social, economic and political factors can be reduced through harmonious education in preschool institutions [11].

Most of the children from the youngest to the senior preschool age have problems with self-regulation behavior. This is especially true of socially vulnerable countries. Educators of senior preschool groups notice that $40 \%$ of children of senior preschool age are prone to manifestations of aggressive and destructive behavior in the form of strikes, pushing, verbal aggression, destruction of the results of someone else's work, ignoring the requests of the educator [12].

Clinical psychology research works to highlight sets of risk factors that increase the likelihood that children in the future may struggle with emotional, social, and cognitive difficulties. Early detection of problems in the field of social development of the child provides the opportunity for timely intervention of specialists and prevention of the formation of negative personal formations [12].

About $16 \%$ of preschool children are found with two or more risk factors. This indicates a high probability that the health and well-being of young children may be in danger. Poverty, cruel upbringing, mistreatment of children, upbringing by one of the parents, lack of a permanent place of residence leads to behavioral disorders in preschool educational institutions and during schooling [12].

Parents often do not realize the serious negative consequences of a violation of social adaptation for the child's psycho-emotional development. The damaging effects of violence and the consequences of injuries associated with it can have an extremely strong effect on the child [12].

Considering all the above, the question of the need for socio-psychological support is of particular importance to harmonize the intellectual and social development of senior preschoolers, compensating for a lack of interpersonal social communication experience, which arises because of the forced "folding" of the role-playing game. Socio-psychological support would guarantee the senior preschool children a successful and non-traumatic transition to schooling as an organized joint activity of the child with other subjects of this activity. The success of which is largely mediated by the quality of interpersonal communication between them. 


\section{Conclusions}

1. Early education and early development of children are closely related to their psychological well-being and personal development. In the case of excessively active and non-professional interventions in these processes in order to accelerate them, it is possible to predict certain deviations and distortions of the child's overall development. Consequently, such interventions require attention and professional socio-psychological support, which presupposes, above all, a high level of professionalism and high personal motivation of all those who carry out early education and early child development.

2. A generalization of the research results by modern psychologists regarding the consequences of early learning has given grounds to state:

- the practice of early learning involves many methods for working with early development and each of these methods can have its own positive and negative impact on the personal development of the child, depending on its individual, social and psychological characteristics;

- it is the motor activity of a child in 1, 2, 3, 4 years that can bring more benefit to its development than cards or cubes with letters. For a start, it is better to go through all successive stages of development: become legs, play street games for children, and so on;

- if you have already started early learning, it is worthwhile to leave the child time to crawl and jump on one leg, participate in children's games, teach it to play simple rhythms modeled on, listen to children's fairy tales and songs, attend puppet shows with the child, and ballet - if it's interesting for a child, to make a story from a picture, to create recurring patterns of cubes, to play various life situations in role-playing games.

\section{References}

[1] Petrunko, O. V. (2010). Dity i media: Sotsializatsiia v ahresyvnomu mediaseredovyshchi. Poltava: TOV NVP „Ukrpromtorhservis”, 480.

[2] Vygotskiy, L. S. (2005). Psikhologiya razvitiya cheloveka. Moscow: Izd-vo Sm'isl; Zksmo, 1136.

[3] Zl'konin, D. B.; Fel'dshteyn, D. I. (Ed.) (1997). Psikhicheskoe razvitie v detskikh vozrastakh. Moscow: Izdatel'stvo «Institut prakticheskoy psikhologii», Voronezh: NPO «MODZK», 416.

[4] Bila, I. M. (2009). Rozvytok piznavalnoi diialnosti doshkilnykiv. Kamianets-Podilskyi: PP Moshynskyi V. S., 120.

[5] Pirozhenko, T. O., Ladyvir, S. O. (2010). Sotsialna sytuatsiia rozvytku suchasnoi dytyny. Doshkilne vykhovannia, 6, 4-9.

[6] Hres, A. (2018). Rozvytok emotsiinoho intelektu. 5-6 rokiv. Kharkiv: Vyd. hrupa «Osnova», 96.

[7] Denysenko, O. I. (2012). Rozvytok navychok komunikabelnosti u ditei doshkilnoho viku. Cherkasy: ChOIPOPP ChOR, 32.

[8] Luriya, A. R. (2000). Vysshie korkove funktsii cheloveka i ikh narusheniya pri lokal'nikh porazhennyakh mozga. Moscow: Vlados, 234.

[9] Dehtiarenko, T. V., Kovylina, V. H. (2010). Stanovlennia psykhiky dytyny ta etapnist rozvytku funktsionalnoi asymetrii pivkul mozku v rannomu ontohenezi. Zbirnyk naukovykh prats Kamianets-Podilskoho natsionalnoho universytetu imeni Ivana Ohiienka. Seriia: Sotsialno-pedahohichna, 15, 32-36.

[10] Harrison, L. J., Goldfeld, S., Metcalfe, E., Moore, T. (2012). Early learning programs that promote children's developmental and educational outcomes. Resource sheet no. 15. Produced for the Closing the Gap Clearinghouse. Canberra: Australian Institute of Health and Welfare \& Melbourne: Australian Institute of Family Studies. Available at: https://researchoutput.csu.edu.au/ws/portalfiles/portal/9387429

[11] Sammons, P.; Sylva, K., Melhuish, E., Sammons, P., Siraj-Blatchford, I., Taggart, B. (Eds). (2010). Does pre-school make a difference? Identifying the impact of pre-school on children's cognitive and social behavioural development at different ages. Early childhood matters: evidence from the Effective Preschool and Primary Education Project. Abingdon: Routledge, 92-113.

[12] Raver, C. C., Knitzer, J. (2002). Ready to enter: what research tells policymakers about strategies to promote social and emotional school readiness among three- and four-year-old children. Promoting the Emotional Well-Being of Children and Families policy paper no. 3. New York: National Center for Children in Poverty, Columbia University, 24. Available at: http://nccp.org/publications/pdf/text_485.pdf Last accessed: 14.01.2011 